Dudás Péter - Balog Margit

\title{
Matematikai-statisztikai paradoxonok alkalmazása a turizmusban
}

Péter Dudás - Margit Balog: Application of mathematical and statistical paradoxes in tourism

\begin{abstract}
The paradox is a well-founded statement / method, derived from a specific area of science and the application possibilities worth to try a different area of the farm in their respective fields. The world of chances and its mathematics is abound of paradoxes. Mathematics and statistics are separate disciplines and related sciences of many areas at the same time. Application of advanced education and research is essential. The study presents analyzing evaluation options in the field of tourism based on two paradoxes (regression and maximum-likelihood) factor analysis and multidimensional scaling analysis.

Keywords: mathematical modeling, multivariate data analysis, tourism
\end{abstract}

\section{ÖSSZEFOGLALÓ}

A paradoxon olyan megalapozott állítás/módszer, amely adott tudományterületről származik és érdemes az alkalmazási lehetőségeit kipróbálni más terület múvelőinek a saját szakterületükön. A véletlenek világa és ennek matematikája bővelkedik paradoxonokban. A matematika és a statisztika önálló tudományok, ugyanakkor sok terület segédtudományai. Alkalmazásuk az igényes oktatásban, kutatásban elengedhetetlen. A tanulmány a turizmus területén két paradoxon (regressziós és maximum-likelihood) alapján faktoranalízissel és többdimenziós skálázással mutat be elemzési, értékelési lehetőségeket.

Kulcsszavak: matematikai modell, többváltozós adatelemzés, turizmus

\section{Bevezetés}

A paradoxon olyan meglepő állítás, amelyet egy adott terület múvelői elképesztőnek tartanak a saját „szakterületükön”, ugyanakkor jól megalapozott állítás/módszer, amely más tudományterületről származik és érdemes az alkalmazási lehetőségeit kipróbálni. A véletlenek világa és ennek matematikája bővelkedik paradoxonokban.

A matematika sajátos helyet foglal el a tudományok rendszerében. Önálló kategória, ugyanakkor sok tudomány segédtudománya. A közgazdaságtudományok területén az újkori matematika eredményei a leginkább használhatók. Ekkor a matematika vezető ága az analízis, „jelszava” a végtelen kicsi. Teret kapott a differenciál-, és integrálszámítás, ami fontos eleme a közgazdaságtudomány megújulásának is (linearizálás, görbék érintői, szélsőérték számítás, határelemzések). Newton, Leibniz, Pascal mellett a kor neves alakja Gauss, akitől a megújulás kiindulását számítják, mivel sok addig megoldhatatlan problémát oldott meg (Filep 2001).

A gazdaságtudományok területén igényesebb munkát végzők mindenképpen találkoznak az analízis, lineáris algebra, valószínűségszámítás alkalmazásával. Bernoulli, Bayes, Csebisev, Fisher, Gauss, Kendall, Kolmogorov, Pearson, Spearman neveihez köthető tételek, mutatók, eloszlások napjainkban már számítógépes könnyen kezelhető programokba beépített elemzési eszközök. Megfelelő használatukhoz kellő mélységú ismeret szükséges. 
A társadalomtudományi kutatások egyik legnehezebb kérdése a megfigyelés és az elmélet közötti kapcsolat megteremtése. Megfigyelni és mérni csak ritkán lehet közvetlenül. A matematikai-statisztikai módszereket használjuk arra, hogy az adatok struktúráját felderítsük.

\section{Alkalmazott módszerek}

Az egyszerúbb módszerek közül a megoszlási és intenzitási viszonyszámokat, átlagokat, grafikus ábrákat használtuk.

A többváltozós adatelemzési módszerek közül a faktorokat maximum-likelihood módszerrel képeztük, hogy a különböző változókat összefogó közös varianciával modellt lehessen készíteni. Így a faktorokkal bemutatható, hogy a háttérváltozók, hogyan alakítják a turizmusteljesítményt mérő vendégéjszakák nagyságát az egyes településeken.

A megfigyelt elemek közti hasonlóságok/különbözőségek interpretálásához a többdimenziós skálázást választottuk. $\mathrm{Az}$ élményvárások vizuális átláthatóságához használtuk.

Az elemzés információs bázisa:

- A KSH 2011. évi területi statisztikáinak turizmusra vonatkozó adatai. A vizsgálat területi dimenziója Jász-Nagykun-Szolnok megye 7 statisztikai kistérsége, ezen belül a mérhető vendégfogadó képességgel, és turisztikai teljesítménnyel rendelkező 37 település.

- A Tiszához 2012 nyarán látogatók, hat helyszínen (Cserkeszőlő, Csongrád, Szeged, Szolnok, Tiszafüred, Tiszakécske). (Magyar Turizmus ZRT Észak-Alföldi Regionális Marketing Igazgatóság kutatásába bekapcsolódva.) Nem reprezentatív, önkényes 355 elemú minta.

Az adatok feldolgozásához, az elemzésekhez az SPSS program 19.0 verzióját használtuk.

\section{A paradoxonok}

A korreláció a sztochasztikus kapcsolatok egyik fajtája, a kapcsolat erősségét, intenzitását számszerűsíti, de a kauzális összefüggés természetét szakmai-logikai vizsgálat hivatott tisztázni, amelyet semmiféle matematikaistatisztikai formula nem pótolhat.

A regresszió kifejezés a lexikon meghatározása szerint hátrálást, visszaesést, visszafejlődést jelent. (Idegen szavak és kifejezések szótára, 1983:720.p.) Matematikai értelemben az angol Sir Francis Galton használta, aki a gyerekek és szüleik testmagassága közötti kapcsolatot tanulmányozta.

A változók helyzete nem szimmetrikus. Az irodalomban többféle elnevezés is használatos. Ezekből néhány:

\begin{tabular}{|l|l|l|}
\hline \multicolumn{1}{|c|}{$y$} & \multicolumn{1}{|c|}{$x_{1}, x_{2}, \ldots, x_{n}$} \\
\hline a) & előrejelzett változó & előrejelző változó(k) \\
b) & regresszált változó & regresszorok \\
c) & magyarázott változó & magyarázó változó(k) \\
d) & függő változó & független változó(k) \\
e) & eredmény változó & ok változó(k) \\
f) & endogén változó & exogén változó(k) \\
g) & célváltozó & kontroll változó(k) \\
\hline
\end{tabular}

Valamennyi kifejezéspár a regressziós elemzés bizonyos szempontjának felel meg. Az a) kifejezéspár az előrejelzések esetén használatos. A b,c,d) kifejezések egyenértékúek, különböző szerzők másképpen használják a regressziós modellek tárgyalásakor. Az e) oksági 
elemzéskor alkalmazható. Az f) az ökonometria jellegzetes kifejezése. A g) elnevezést irányításelméleti (ellenőrzési) problémák elemzéshez használják.

A regressziós függvények a kapcsolatban rejlő tendenciát, törvényszerűséget függvénnyel írják le. Nem a legpontosabb görbe illesztése a cél, hanem a tendencia megállapítása. Azt a függvényt célszerű választani, amelyiknél a tényleges pontoknak a regressziós függvény értékeitől mért átlagos távolsága a legkisebb. Ehhez a legkisebb négyzetek módszere alkalmazható. Ez a követelmény egy többváltozós szélsőérték feladathoz vezet, amelyből a normálegyenletek származnak. A legkisebb négyzetek elve mellett szól a GaussMarkov tétel is: "a legkisebb négyzetek módszerével kapott regressziós együtthatók a sokasági paraméterek legjobb lineáris torzítatlan becslései, ami annyit jelent, hogy szórásuk kisebb, mint az egyéb módszerekkel nyerhető más becslö függvények szórása" (Matematikai kislexikon, 1979. 133.p.).

Matematikailag bizonyítható, hogy az egység megválasztása befolyásolja az eredményt. Az aggregálás erősíti a kapcsolatot, az egységek egyre nagyobb csoportokba történó összevonásával a korreláció egyre szorosabbá válik. Ez a jelenség a nagy számok törvényével magyarázható: a kis egységeknél megfigyelhetó tendenciát még erősen befolyásolják a véletlen jellegú körülmények, a nagyobb csoportoknál viszont a véletlen hatása gyengül és a tendencia élesebbé válik.

Gyakran előfordul, hogy néhány szélsőséges megfigyelés vagy kiugró érték jelentősen befolyásolja a regressziós együtthatók becslését. A kiugró érték (outlier) olyan megfigyelés, amely távol esik a többi megfigyeléstől, általában valamilyen szokatlan tényező okozza. Ezt akkor lehet kimutatni, ha megvizsgáljuk a becsült regressziós egyenlet maradék tagjait. Abban az esetben, amikor a legkisebb négyzetek módszerét alkalmazzuk, egyetlen kiugró megfigyelés is jelentősen módosíthatja a regressziós egyenletet.

\section{A többváltozós lineáris regresszió}

A többváltozós modell specifikálása esetén figyelembe kell venni, hogy egy adott jelenségnél az eredményváltozó lehet egy másik viszonylatban tényezőváltozó. Ezért a gazdasági problémák matematikai modelljét nem lehet egyetlen regressziós egyenlettel leírni.

Egy adott probléma esetén át kell tekinteni a szóba jöhető változókat. Beléphetnek minőségi ismérvek is, mert a többváltozós modellben alternatív ismérvek formájában ezek is szerepelhetnek. A gyakorlatban itt is első közelítésben lineáris modellt szokás alkalmazni.

\section{Többszörös nemlineáris regresszió}

A lineáris egyenlet gyakran elég jól leírja a változók közti összefüggést, ugyanakkor előfordulnak olyan problématípusok, ahol a lineáris összefüggések kevésbé használhatók. Ilyen lehet, amikor a magyarázó tényezőknek van egy optimális értéke; ezen érték alatt vagy felett csökken a termelés/forgalom/fogyasztás. Itt nem használható a lineáris regresszió, tehát nemlineáris regressziót kell meghatározni, miközben kizárjuk más tényezők hatását, amelyek hatnak a független változóra (EzekielFox 1970).

Tehát ha $y$ a függő változó és $x_{1}, x_{2}, x_{3}, \ldots$ a független változók, $y$ értékének változásait a független változóktól a következő regressziós egyenlettel lehet becsülni:

$$
y=a+f_{1}\left(x_{1}\right)+f_{2}\left(x_{2}\right)+f_{3}\left(x_{3}\right)+\ldots
$$

Az $f_{1}\left(x_{1}\right), f_{2}\left(x_{2}\right)$ általános jelölés azt jelenti, hogy $y$ függvénye $x_{1}$-nek, plusz $x_{2}$-nek, stb. A különböző parciális regressziós görbéket matematikai formában lehet megadni minden független változóra egy-egy függvénnyel.

\section{Faktorelemzés}

A faktorelemzés több módszer összefoglaló neve, amelyek adatredukcióra és adatstruktúra feltárására szolgálnak. Az elemzésbe bevont változók számának csökkentésére, illetve a változók között feltárható struktúrák azonosítására használhatók (Kovács 2003). 
A módszerek a variancia felbontásából indulnak ki, abból a feltételezésből, hogy a teljes varianciának három összetevője van: közös variancia (több változó mögött húzódik), egyedi variancia (egy változó mögött csak egy faktor van), hibavariancia (mérési hiba, vagy véletlen hatás eredménye lehet). Az alapvető különbség a módszereknél döntően a felbontásban van.

Hajdu (2004) megfogalmazásában az exploratív faktoranalízis célja a faktorsúlyok minél egyszerúbb struktúrájának feltárása a megfigyelt indikátorokból kiindulva. A legegyszerúbb a struktúra, ha egy indikátort csak egyetlen faktor magyaráz nem zéró súllyal. Az ilyen indikátor komplexitása egységnyi.

\section{Maximum likelihood paradoxon}

$\mathrm{Az}$ ismeretlen paraméterek becslésének egyik hatékony módszere. A módszer alkalmazásában a XX. század elején Fisher ért el áttörést. A maximum-likelihood módszer (a legnagyobb valószínúség elve) lényege: az ún. likelihood függvény a mintaelemek együttes sűrűségfüggvénye, és az ismeretlen paraméter becslésére azt a statisztikát használjuk, melyre ez a függvény maximális értéket vesz fel.

\section{Többdimenziós skálázás}

A többdimenziós skálázás az adatok közötti különbségeket vizualizálja, és az adatok rejtett struktúráját vizsgálja. A faktoranalízis alternatívája. A skálázó modellekben az objektumok az állapottér pontjaiként jelennek meg olyan módon, hogy a hasonló objektumok közel kerülnek egymáshoz (Füstös et.al. 2004). A skálázás feladata, hogy a minimális

A Stress mutató egyenlete

$$
S=\sqrt{\frac{\sum_{\mathrm{i}=1}^{\mathrm{n}} \sum_{\mathrm{j}=1}^{\mathrm{n}}\left(d_{i j}-f\left(\delta_{i j}\right)\right)^{2}}{\sum_{\mathrm{i}=1}^{\mathrm{n}} \sum_{\mathrm{j}=1}^{\mathrm{n}}\left(d_{i j}\right)^{2}}}
$$

dimenziószámú térben olyan ponthalmazt találjon, hogy a térbeli távolságok monoton függvényei legyenek az adatok közötti különbözőségeknek. A követelmény, hogy az elemek közötti távolság a redukált térben (bizonyos hiba határon belül) ugyanolyan legyen, mint az eredeti távolság. Az eljárás a származtatott koordináták közötti távolságokat összeveti az eredetileg ismert különbségekkel, és törekszik az eltérés minimalizálására. (Kovács 2003).

Az eljárás eredménye egy ponthalmaz "képe”, amit térképnek is szoktak nevezni. Az illeszkedés jóságát különböző stressz-mutatók alapján lehet megítélni. A Stress szemléletes jelentése: a modell által meghatározott térben az összes észlelt különbözőséghez képest mekkora az ezen elméleti távolságok és a modell által létrehozott pontkonfigurációban ténylegesen létrejött távolságok eltérése. Tehát, ha tökéletes a megfelelés az eredetileg érzékelt és az ábrázolt különbségek között, akkor a hiba zérus és így a Stress értéke is az.

Az MDS alapegyenlete: $d_{i j}=f\left(\delta_{i j}\right)$.

Magyarázat: Adott $n$ objektum, és a rajtuk értelmezett $\delta_{\mathrm{ij}}$ (az $i$. és a $j$. elem tényleges különbsége), a $p$ dimenziós térben. Az MDS alacsonyabb dimenzióba rendezi a pontokat, amelyek az objektumokat reprezentálják. Az elvárás, hogy a térbeli távolságok monoton függvényei legyenek az adatok közti különbségeknek. Tehát ha $\delta_{\mathrm{ij}}<\delta_{\mathrm{kl}}$, akkor $\mathrm{d}_{\mathrm{ij}} \leq$ $d_{k l}\left(d_{i j}\right.$ a képzett térben az $i$. és $j$. elem különbsége). A gyenge monotonitás megengedett.

\begin{tabular}{c|c}
\hline S értéke & Minösités \\
\hline $0-0,05$ & kiváló \\
$0,05-0,10$ & jó \\
$0,10-0,20$ & elfogadható \\
0,20 felett & magasabb dimenzió \\
& szükséges \\
\hline \multicolumn{2}{c}{ (Füstös et.al. 2004) }
\end{tabular}


Dudás Péter - Balog Margit: Matematikai-statisztikai paradoxonok alkalmazása a turizmusban

\section{Eredmények}

A mérhető turizmus teljesítmény Jász-NagykunSzolnok megyében

Az értékelés az 1000 állandó lakosra jutó vendégéjszaka mutatóval történt. A települések számára bevételt jelentő turistaköltés a vendégéjszaka eltöltéséhez biztosan társul. A településnek a vendégéjszakát nem töltő vendégektől is származik jövedelme, de makrogazdasági szinten sem megoldott ennél jobb mutató a teljesítményméréshez (Kóródi 2006).

\begin{tabular}{l|c}
\hline 1. kategória & 10 alatt \\
\hline 2. kategória & $10,1-30$ \\
\hline 3. kategória & $30,1-50$ \\
\hline 4. kategória & $50,1-100$ \\
\hline 5. kategória & $100,1-200$ \\
\hline 6. kategória & 200 felett \\
\hline
\end{tabular}

1. táblázat

A turizmusteljesítmény a megyei átlag
A részletesebb vizsgálathoz a vendégéjszakák eloszlását 2 szempont szerint rendeztük:

- Településszinten 1000 állandó lakosra vetítve (ezzel kimutatva, a település nagyságához viszonyított jelentőségét és hogy milyen erőfeszítést jelent a vendégfogadás).

- A megyei átlaghoz viszonyítva, kategorizálva (ez kissé szubjektív csoportosítás, de több év adatait vizsgálva egyenlő osztályközök szóba sem jöhetnek, és a kialakított kategóriák stabilnak mondhatók). \%-ában

Látható, hogy néhány település magasan átlag feletti turizmusteljesítményű. A megyei átlag több mint kétszeresénél is magasabb (6. kategória) a vendégéjszakák száma Berekfürdőn és Cserkeszőlón. Szintén magasabb az átlagnál (5. kategória) Abádszalók és a Jászberényi kistérségben Jászszentandrás turisztikai teljesítménye. Mind a négy település különbözó kistérségbe tartozik, tehát egyedül képesek a kistérségi mutatókat kedvezően alakítani.

A vendégforgalom alakulására ható tényezők A vendégéjszakák alakulására ható tényezők meghatározásához többváltozós lineáris regressziós modell készült. a legkisebb négyzetek elve alapján. Az elemzés JászNagykun-Szolnok megye településsoros kistérségi 2011. évi adataiból készült.

\begin{tabular}{|c|c|c|c|c|c|c|c|}
\hline \multirow[b]{2}{*}{ Kistérség } & 1 & 2 & 3 & 4 & 5 & 6 & \multirow[b]{2}{*}{ Össz. } \\
\hline & \multicolumn{6}{|c|}{$\begin{array}{l}\text { kategóriába tartozó } \\
\text { települések }\end{array}$} & \\
\hline Jászberényi & - & 2 & 2 & - & 1 & - & 5 \\
\hline Karcagi & 2 & - & - & - & - & 1 & 3 \\
\hline Kunszentmártoni & 2 & 2 & - & - & - & 1 & 5 \\
\hline Mezőtúri & - & 1 & 1 & 1 & - & - & 3 \\
\hline Szolnoki & 3 & 3 & 2 & 1 & - & - & 9 \\
\hline Tiszafüredi & 6 & 1 & - & 1 & 1 & - & 9 \\
\hline Törökszentmiklósi & 2 & - & 1 & - & - & - & 3 \\
\hline Összesen & 15 & 9 & 6 & 3 & 2 & 2 & 37 \\
\hline
\end{tabular}

Az egyes kategóriákba tartozó települések száma kistérségenként

Forrás: Saját számítás

A modell "stepwise" módszerrel készült, így egyenként léptek a modellbe azok a változók, amelyek szignifikánsan befolyásolják a függő változó értékeinek alakulását (minden mutató 1000 lakosra vetítve).

A független változók:

- kereskedelmi szállásférőhely (kerfh_1000lakos),

- egyéb szállásférőhely (egyebfh_1000lakos),

- vendéglátóhely (vendlhely_1000lakos).

A függő változó: vendégéjszaka (vendéj_1000lakos).

Mivel a változók lépésenkénti módszerrel kerültek a modellbe, a magyarázóerő fokozatos növekedését jól mutatja a 3 . táblázat. 


\begin{tabular}{|c|r|r|r|}
\hline Modell & $\mathrm{R}$ & $\mathrm{R}^{2}$ & korrigált $\mathrm{R}^{2}$ \\
\hline 1 &, $961(\mathrm{a})$ &, 923 &, 921 \\
2 &, $983(\mathrm{~b})$ &, 967 &, 965 \\
3 &, $985(\mathrm{c})$ &, 971 &, 968 \\
\hline
\end{tabular}

a) A változók: kerfh_1000lakos;

b) A változók: kerfh_1000lakos, egyebfh_1000lakos

c) A változók: kerfh_1000lakos, egyebfh_1000lakos, vendlhely_1000

3. táblázat: A regressziós modellváltozók magyarázóerejének alakulása „lépésenként"

Forrás: Saját számítás

Legnagyobb magyarázóerővel a kereskedelmi szállásférőhelyek száma bír, a vendégéjszakák varianciájának $\approx 92 \%$-át magyarázza. A következő változó (egyéb szállásférőhelyek) az előzőhöz $\approx 4 \%$ pontot ad. Ezt még nagyon kevés magyarázattal egészíti $\mathrm{ki}, \quad\left(\begin{array}{ll}1 \% & \text { sincs}\end{array}\right)$ de megemlíthető magyarázóváltozó a vendéglátóhelyek száma. A variancia-analízis tábla is azt mutatja, hogy szignifikáns a képzett regresszió.

\begin{tabular}{|l|r|r|r|r|r|}
\hline \multicolumn{1}{|c|}{ Model } & \multicolumn{1}{c|}{ Sum of Squares } & \multicolumn{1}{c|}{ df } & Mean Square & \multicolumn{1}{c|}{$\mathrm{F}$} & \multicolumn{1}{c|}{ Sig. } \\
\hline Regression & $9,3 \mathrm{E}+009$ & 3 & 3083646590 & 368,344 &, 000 \\
Residual & $2,8 \mathrm{E}+008$ & 33 & 8371644,1 & & \\
Total & $9,5 \mathrm{E}+009$ & 36 & & & \\
\hline
\end{tabular}

4. táblázat: A regressziós modellek szignifikancia vizsgálata variancia-analízissel

Forrás: Saját számítás

Az előbb említetteket igazolja a parciális teszt is. A férőhelyek száma egyértelműen fontos változók, és a harmadik változó hibaszintje is
$5 \%$ alatt van. A standardizált $\beta$ együtthatók is megerősítik a változók súlyát a modellben.

\begin{tabular}{|l|c|r|r|}
\hline \multicolumn{1}{|c|}{ Model } & $\begin{array}{c}\text { Standardized } \\
\text { Coefficients Beta }\end{array}$ & \multicolumn{1}{c|}{$\mathrm{t}$} & \multicolumn{1}{c|}{ Sig. } \\
\hline kerfh_1000lakos & 1,694 & 15,171 &, 000 \\
egyebfh_1000lakos &, 594 & 6,571 &, 000 \\
vendlhely_1000lakos &, 184 & 2,078 &, 046 \\
\hline
\end{tabular}

5. táblázat: A regressziós modell paramétereinek parciális szignifikancia vizsgálata

Forrás: Saját számitás

A magyarázó változók függetlenségére vonatkozó elvárás fontos. A lépésenkénti modellezésnél különösen indokolt a modellbe bevont magyarázó változók közötti korreláció, a multikollinearitás mérése. Ehhez a szakirodalomban is ajánlott két mutatót határoztunk meg.

- Tolerancia: annak a determinációs együtthatónak a komplementere, amely azt méri, hogy az i-edik magyarázó változót az összes többi milyen szorosan határozza meg.

- Variancia infláló faktor: [VIF] a tolerancia reciproka. Ha a magyarázó változók között szoros kapcsolat van, a VIF végtelen nagy lehet, ha ortogonálisak, akkor egységnyi. (Ha VIF értéke 1 és 2 között van, gyenge; 2 és 5 között erős, zavaró; 5 felett káros a multikollinearitás.) 


\begin{tabular}{|l|r|r|}
\hline \multirow{2}{*}{\multicolumn{1}{|c|}{ Model }} & \multicolumn{2}{|c|}{ Collinearity Statistics } \\
\cline { 2 - 3 } & \multicolumn{1}{|c|}{ Tolerance } & \multicolumn{1}{c|}{ VIF } \\
\hline kerfh_1000lakos &, 193 & 5,190 \\
egyebfh_1000lakos &, 303 & 3,304 \\
vendlhely_1000lakos &, 340 & 2,938 \\
\hline
\end{tabular}

6. táblázat: A multikollinearitás vizsgálata a regressziós modellben

Forrás: Saját számitás

Összességében megállapítható, hogy a készített többváltozós lineáris regressziós modellben a $t$ és $F$ próbák szerint is megfelelőek a bevont paraméterek, ugyanakkor a tolerancia és VIF értékek azt mutatják, hogy összefüggés van a magyarázó változók között. Mivel a modellből kimaradtak olyan változók, amelyek feltételezésünk szerint hatnak a vendégéjszakák alakulására, esetleg nem egyenként, hanem csoportosan ( $\mathrm{pl}$. a település infrastruktúrája, városi-vidéki jellege) ezért többváltozós elemzést végeztünk.

\section{A turizmusteljesítményt alakító tényezők meghatározása faktoranalízissel}

Egy adott jelenség tanulmányozásához először össze kell állítani a figyelembe vehető változókat. Ezek közül is a mérhetőket. A 37 településre vonatkozóan a vizsgálatba 8 szignifikáns változó került, amelyek elég erősek ahhoz, hogy jellemezzék a turizmus teljesítményt alakító vendégfogadó képességet, és a település jellemzőket. Mivel az abszolút adatok extrém értékeket is tartalmaznak, intenzitási viszonyszámokat képeztünk.

A többváltozós lineáris modellbe került változók egyértelmúen a turisztikai kínálat elemei, de valószínű, hogy más háttérbeli változók is hatnak. Ennek meghatározása azért is fontos, mert az adott település teljesítményét a versenytárs desztinációk is befolyásolják, ugyanis helyettesítő "termékként” a turista választási és döntési lehetőségei között szerepelnek.

Jász-Nagykun-Szolnok megye érintett településeinek turisztikai teljesítményét maximum-likelihood módszerrel képzett faktorokkal elemeztük.

\begin{tabular}{|c|c|c|}
\hline \multirow{2}{*}{ Változók } & \multicolumn{2}{|c|}{ Faktor } \\
\hline & 1 & 2 \\
\hline 1000 lakosra jutó férőhelyek száma egyéb (2009-ig magán) szálláshelyeken & ,990 & 006 \\
\hline 1000 lakosra jutó férőhelyek száma kereskedelmi szálláshelyeken & ,983 & 079 \\
\hline 1000 lakosra jutó szálláshely szolgáltató vállalkozások száma & ,968 &,- 005 \\
\hline 1000 lakosra jutó vendéglátóhelyek száma & ,952 & 039 \\
\hline 1000 lakosra jutó személyi jövedelemadó &,- 015 & ,887 \\
\hline népsürűség &,- 159 & ,836 \\
\hline 1000 lakosra jutó kereskedelmi vállalkozások száma & 149 & ,804 \\
\hline 1 km vízhálózatra jutó csatorna & 159 & ,730 \\
\hline 1000 lakosra jutó mezőgazdasági vállalkozások száma & 014 &,- 638 \\
\hline
\end{tabular}

\section{Extraction Method: Maximum Likelihood}

7. táblázat: Faktorsúlyok 
Az 1. faktorba azok a változók kerültek, amelyek közvetlenül a vendégfogadással kapcsolatosak $\rightarrow$ fogadókapacitás faktor (az összes variancia $43 \%$-át magyarázza).

A 2. faktor alkotói a települések demográfiai, gazdasági, infrastrukturális jellemzőivel, illetve a turizmus hátterével vannak összefüggésben. Negatív előjel a vidékies, pozitív előjel a városi tulajdonságot erősíti $\rightarrow$ vidéki-városi jelleg faktor (az összes variancia 34\%-át magyarázza).

Tehát a vendégéjszakák alakulását 8 változóból képzett 2 faktorral határoztuk meg, amelyek az összes variancia $77 \%$-át magyarázzák. Az 1 . és 2. ábrán a vízszintes tengelyt az átlagos vendégéjszaka szintjéhez eltolva szemléletes az átlagot meghaladó, és az átlag alatt teljesító

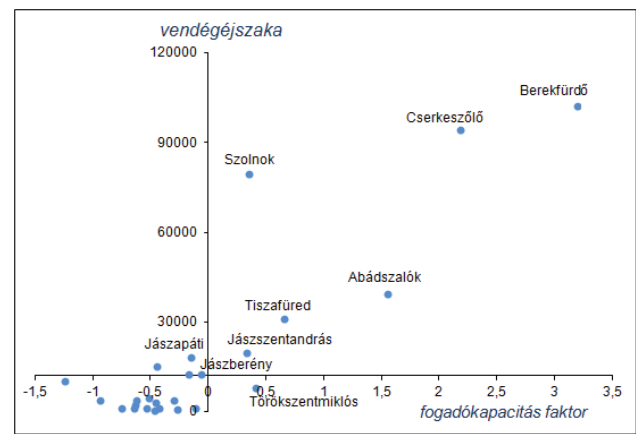

1. ábra:

A vendégéjszaka és az 1 . faktor kapcsolata

Másodlagos turisztikai motivációk rendszerbe rendezése

A vízi turizmus és a vízparti települések turizmusa általában jelentős vonzerőnek számít. Olyan Tisza parti települések kerültek be a vizsgálatba, amelyek turizmusát a vízhez való kötődés valószínúleg nagymértékben befolyásolhatja. A kutatás ebben az esetben „átlépte” a megyehatárt, ami azért nem zavaró, mert egyrészt a hat megfigyelési helyszín fele a megyében van, kettő szinte a megyehatáron; másrészt igazolódik a tájegységi fontosság, ami a turizmus elemzésénél lényeges. települések helyzete. Ebben az értelmezésben az I. negyedbe kerültek azok a települések, amelyek átlag feletti fogadókapacitással rendelkeznek, és turisztikai teljesítményük is átlag feletti. Ez utóbbi szerint több csoportot alkotnak: 1. Berekfürdő, Cserkeszőlő (a megye jelentős üdülöhelyei), 2. Szolnok (a „nagyváros”), 3. Abádszalók, Tiszafüred (a Tisza tó városai). A vidéki-városi jelleg kevésbé elkülönítő erő, gyakorlatilag a megyeszékhelyen, illetve jóval kisebb mértékben az egyéb városokban mutatható ki. Megjegyzendő, hogy a vonzerő, melyet ebben a tanulmányban nem vettünk számításba, tovább differenciálja a településeket, hiszen más a funkciója a városi, a falusi, a vízhez kötődő (gyógyvíz, Tisza, Tisza-tó) turizmusnak. Ezek figyelembevételével tovább árnyalhatók a települési adatok.

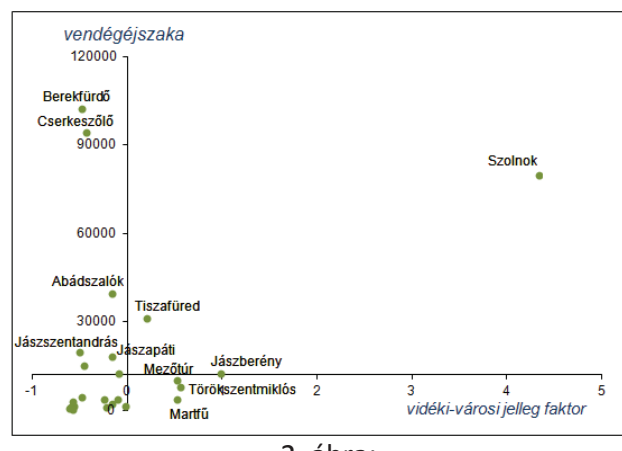
2. ábra:

A vendégéjszaka és a 2 . faktor kapcsolata Forrás: Saját számítás alapján szerkesztett

Meg kell említeni, hogy a vízi turizmusban részt vevők egy része nem vesz igénybe sem kereskedelmi, sem magánszálláshelyet, tehát ebból a szempontból rejtve maradnak a hivatalos statisztika számára. A vízparti turisztikai motivációk a tiszai turizmusban résztvevők körében végzett primer kutatás eredményei alapján kerültek elemzésre.

A kérdések egy része megfelel az országos turisztikai adatgyújtésnek, ami minden évben felmérésre kerül. 2012-ben a Magyar Turizmus ZRT Észak-Alföldi Regionális Marketing Igazgatóság kutatásába bekapcsolódva a 
kutatás a turisták motivációi mellett hangsúlyt fektetett a turisták élményelvárásaira.

A lekérdezés időszaka csaknem az egész tiszai turisztikai szezont lefedte, 2012. július 3-tól augusztus 30-ig tartott. A megkérdezettek a tiszai turizmusban résztvevők közül kerültek ki.

\section{Az elvárt tényezők rendszerezése}

A többváltozós adatelemzések közül a többdimenziós skálázást választottuk. A módszerrel értékelésre került, hogy a Tiszához érkezők elvárásai, milyen fontosabb dimenziókra szúkíthetők. Így kétdimenziós térben elhelyezve a változókat, feltárható a vendégek szubjektív értékelése.

\begin{tabular}{|cc|}
\hline $\begin{array}{c}\text { Iteration history for the } 2 \text { dimensional } \\
\text { solution (in squared distances) }\end{array}$ \\
\hline Iteration & Improvement \\
\hline 1 &, 01654 \\
2 &, 00373 \\
3 &, 00165 \\
4 &, 00069 \\
5 & Iterations stopped because \\
\hline \multicolumn{2}{|c|}{ For matrix } \\
S-stress improvement is less than ,00100 \\
\hline \multicolumn{2}{|c|}{ Stress = 07747 $\quad$ RSQ =,97326 } \\
\hline
\end{tabular}

8. táblázat: A számítások eredménye Forrás: Saját számítás
A Stress mérték az utolsó iteráció után 0,07747, tehát az elkészült modell jól illeszkedik az eredeti térben a véleményekre alapozott távolságokhoz, így nincs szükség a dimenziószám növelésére. (Amikor az egy lépéssel elérhető javulás 0,001 alá csökken, nem érdemes továbblépni.) Ezt megerősíti, hogy a távolságokra vonatkozó monotonitási követelményt mérő $R^{2}$ értéke 0,97326.

Az értelmezéshez a módszer megköveteli a tengelyek interpretálását. Úgy gondolom, hogy a tengelyek elforgatása nélkül is megállapítható, hogy az 1. dimenzió a vízhez kapcsolódó programok jelentőségére utal, (minél jobbra helyezkedik el a pont, annál fontosabb a víz szerepe) ami természetes, mivel ez az elsődleges motiváció, ezért van értelme ilyen desztinációba érkezni. A 2. dimenzió a háttérprogramok erőssége, intenzitása szerint szelektálja az elvárásokat, (minél fentebb helyezkedik el a pont, annál élménydúsabb, nyüzsgőbb program az elvárás) tehát megerősíti azt a hipotézist, hogy létezik a másodlagos motiváció, amelyet érdemes megismerni, értékelni.

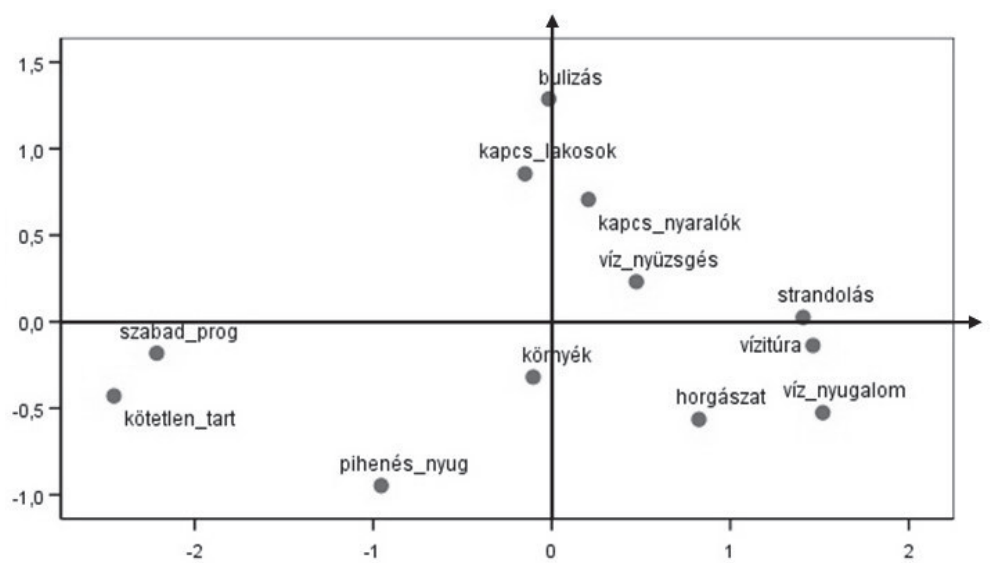

4. ábra: A koordinátáknak megfelelő pontok elhelyezkedése a kétdimenziós térben

Forrás: Saját számítás alapján szerkesztett 


\section{Összegzés}

Rényi Alfréd neves matematikus megállapításával egyetértve „a matematika bizonyos tekintetben az összekötő kapocs a különböző tudományok között". Valóban, ha meg lehet mérni és számokban kifejezhető az, amiről beszélünk, akkor valamit tudunk róla.

A turizmussal összefüggő szekunder és primer adatok elemzése után a következők állapíthatók meg:

- A kutatás rámutat, hogy a matematikaistatisztikai módszerek alkalmasak arra, hogy az adatok struktúráját felderítsük.

- A regressziós paradoxon megfelelő óvatossággal alkalmas a turisztikai teljesítmény értékeléséhez, de a magyarázó tényezők nagy száma miatt gyakran előfordul kiugró érték, multikollinearitás, ami befolyásolja a regressziós együtthatók becslését.
- A maximum likelihood paradoxon turisztikai alkalmazása újszerū. A módszer az ismeretlen paraméterek becslésének egyik hatékony módszere. Segítségével megállapítást nyert, hogy a vendégéjszakák nagyságát alapvetően 2 fő tényezőcsoport alakítja: az adott település fogadókapacitása, ami önmagában is vonzerő, és a település típusa, ami szintén lehet vonzerő, attól függően, hogy a turistát mi motiválja.

- A többdimenziós skálázás, mint a faktoranalízis alternatívája, az adatok közötti különbségeket vizualizálja. Turisztikai alkalmazásával a módszerrel értékelésre került, hogy a Tiszához érkezők elvárásai, milyen fontosabb dimenziókra szúkíthetők. Így elkülöníthető az alapmotiváció, és a másodlagos motiváció, amelyet érdemes megismerni, értékelni.

\section{IRODALOM}

[1] Backhaus, K. et.al. (2000):Multivariate Analysemethoden, Springer, Berlin, 253-298.p.

[2] Bartholomew, D.J. (1987): Latent variable models and Factor Analysis. London: Oxford University Press, 39-65

[3] Borgatta, E.F.-Bohrnstedt, G.W. (1980): Level of measurement - Once over again. Sociological Methods and Research, 9 (2) 147-160.p.

[4] Ezekiel, M.-Fox, K. (1970): Korreláció- és regresszió analízis. Budapest: KJK, 58-71.p.

[5] Filep L. (2001): A tudományok királynője (A matematika fejlődése). Budapest: Typotex, 2528; 157-165.p.

[6] Füstös L. et.al. (2004): Alakfelismerés. Budapest: Új Mandátum Kiadó, 11-45.p.

[7] Hajdu O. (2004): Rotáció az egyszerú faktorstruktúráért. Statisztikai Szemle, 82 (10-11) 978990.p.

[8] Hartung, J.-Elpelt, B. (1984) Multivariate Verfahren. Hagen, 124p.

[9] Kóródi M. (2006): A vidéki turizmusfejlesztés összefüggései a magyarországi kistérségekben. Doktori értekezés SZIE, Gödöllő, 65-84.p.

[10] Kovács Erzsébet (2003): Többváltozós adatelemzés. Aula, Budapest, 71-87.p.

[11] Maddala, G.S. (2004): Bevezetés az ökonometriába. Budapest: Nemzeti Tankönyvkiadó, 3351.p.

[12] Sajtos L.-Mitev A. (2007): SPSS kutatási és adatelemzési kézikönyv. Alinea, Budapest, 245281.p.

[13] Simon J. (1993): Piacanalízis II. Többváltozós módszerek a piackutatásban. BKE, 77p.

[14] Székely J.G. (2004): Paradoxonok a véletlen matematikájában. Budapest: Typotex Kiadó, 300-373.p. 